\title{
Morphometric Evaluation of Parasagittal Venous Anatomy for Intracranial Approaches: A Cadaveric Study
}

\author{
Intrakranyal Yaklaşımlar için Parasagital Venöz Anatominin \\ Morfometrik Değerlendirmesi: Kadavra Çalışması
}

\author{
Salih SAYHAN ${ }^{1}$, Mustafa GUVENCER ${ }^{2}$, Ercan OZER ${ }^{3}$, Mehmet Nuri ARDA $^{3}$ \\ ${ }_{1}^{1}$ Denizli State Hospital, Department of Neurosurgery, Denizli, Turkey \\ ${ }^{2}$ Dokuz Eylul University Hospital, Department of Anatomy, Izmir, Turkey \\ ${ }^{3}$ Dokuz Eylul University Hospital, Department of Neurosurgery, Izmir, Turkey
}

Correspondence address: Salih SAYHAN / E-mail: sayhansalih@yahoo.com, salih.sayhan@gmail.com

\begin{abstract}
AIM: Obstruction of superior sagittal sinus (SSS) and collateral bridging veins is a well-known reason of postoperative brain edema and brain infarct, however, morphometric anatomic studies done in the light of surgical landmarks aren't sufficient in number. Object of this study is to describe venous structures related to SSS with silicon injected cadaveric models.

MATERIAL and METHODS: This study was on 6 silicon injected cadaveric heads at Anatomy Department. Duramater was removed and veins on parasagittal area were examined. SSS morphology, veins draining into SSS, their size, number and distance were evaluated.

RESULTS: Mean vein number draining into SSS is $2.9 \pm 1.5$ at anterior to coronal suture (CS), between CS and vertex is $3.2 \pm 0.8$, between vertex and lambdoid suture (LS) is $2.3 \pm 0.9$, between $L S$ and confluens sinuum $0.3 \pm 0.5$. There was no statically difference between right and left sides $(p=0.140, p>0.05)$. Diameter of veins was $2.4 \pm 1.0 \mathrm{~mm}$ at anterior to $C S, 3.0 \pm 1.2 \mathrm{~mm}$ at between CS and vertex, $2.4 \pm 0.7 \mathrm{~mm}$ at between vertex and LS, and $2.2 \pm 0.5 \mathrm{~mm}$ at between $\mathrm{LS}$ and confluens sinuum.
\end{abstract}

CONCLUSION: Knowing details of anatomic structures of SSS and venous structures draining into it may protect the patients from many surgical complications. SSS and related structures with surgical landmarks are valuable for neurosurgeons.

KEYWORDS: Superior sagittal sinus, Parasagittal venous anatomy, Intracranial superficial veins

öz

AMAÇ: Sagital sinüs ve kolleteral asıcı venlerin tıkanıklığı iyi bilinen, postoperatif beyin ödemi ve beyin infarktüsü sebebidir. Ancak cerrahi landmarklar ışığında yapılan morfometrik anatomik çalışmalar sayıca yetersizdir. Bu çalışmada amacımız, superior sagital sinüs ve ilişkili venöz yapıları silikon injekte edilmiş kadavra modelleri ile göstermektir.

YÖNTEM ve GEREÇLER: Bu çalışmada, anatomi bölümünde bulunan 6 silikon enjekte edilmiş kadavra kafası kullanıldı. Duramater kaldırıldıktan sonra parasagital alandaki venler disseksiyonla ortaya kondu. Superior sagittal sinüs (SSS) morfolojisi değerlendirildi, SSS'ye dökülen venlerin sayıları, boyutları ve uzaklıkları ölçüldü.

BULGULAR: Koronal sütür anteriorunda SSS'ye dökülen ortalama ven sayısı 2,9 $\pm 1,5$, koronal sütür ile verteks arasında 3,2 $\pm 0,8$, verteksle

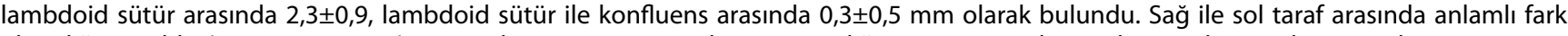
olmadığı görüldü $(p=0,140, p>0,05)$. Koronal sütür anteriorunda ven genişliği $2.4 \pm 1.0 \mathrm{~mm}$, koronal sütür ile verteks arasında $3,0 \pm 1,2 \mathrm{~mm}$, verteksle lambdoid sütür arası $2,4 \pm 0,7 \mathrm{~mm}$, lambdoid sütür ile konfluens arasında ise $2,2 \pm 0,5 \mathrm{~mm}$ olarak ölçüldü.

SONUÇ: SSS ve ona dökülen venöz yapıların anatomik detaylarının bilinmesi pek çok cerrahi komplikasyondan hastaları koruyabilir. Yine landmarklarla venöz yapıların ilişkisi nöroşirürjiyenler için değerli olabilir.

ANAHTAR SÖZCÜKLER: Superior sagittal sinüs, Parasagittal venöz anatomi, İntrakranyal superfisiyal venler

\section{INTRODUCTION}

Intracranial venous structures have received increasing attention from neurosurgeons with regards to postoperative complications and from neurologists with regards to improved neuroimaging techniques and increased awareness of cerebral venous disease. Most unpredictable post operative complications are likely to be related to the lack of recognition of venous problems. In particular, damage to the superior sagittal sinus (SSS) may cause major neurological deficits. Cortical venous infarction is one important complication occasionally affecting outcome in brain tumours (8). Similarly, venous sinuses are at risk whenever a pathological process 
directly involves them. Also, surgical procedures may cause venous infarction; neurosurgeons mostly use the anterior inter hemispheric approach for distal anterior cerebral artery aneurysms, but a frontal parasagittal bridging vein is occasionally sacrificed in this approach, creating a risk of postoperative venous infarction (10). Cerebral veins may be damaged during operations by three mechanisms: intentional coagulation and division to prevent their rupture, traction during an operation from their fixed drainage sites (into a dural sinus) causing their rupture, or damage during their dissection in the brain. Veins are more liable to be damaged than arteries because they have thinner walls, and are not as tortuous as arteries, allowing them less ability to be manipulated before rupture. Additionally, both basal and convexity operations put them at stretch and at risk for rupture, whereas arteries are mainly stretched during basal operations (13).

Making the intracranial veins visible by means of maintaining colored liquid circulation on cadavers $(1,5)$ and defining their courses, numbers and the relations among veins by means of filling with coloured silicon, latex etc. (11) are of great importance for a surgeon to define the anatomic characteristics of the region more clearly before the operation.

The aim of the study is to show the SSS and its draining veins in relation to surgical landmarks. The results of this study may be a useful guide to neurosurgeons who deal with the SSS and related structures.

\section{MATERIAL and METHODS}

This study used six heads belonging to adult male cadavers fixed in formaldehyde and injected with colored silicon, which had no pathology and no surgical scars from the laboratories of Dokuz Eylul University Faculty of Medicine, Department of Anatomy.

\section{Colored Silicon Injection}

The cadaveric head was sectioned through the neck with an oscillating saw in the anatomy laboratory. The section was made as low as possible in the neck, which provided easy cannulation.

The vessels were tightly sutured to the cannulation tubes with 2-0 sutures. This was done in order to avoid frustrating dislodgement of the cannulation during the injection process. Cannulated vessels were irrigated with hot tap water for nearly 2 months.

The silicone (3110 RTV silicone rubber; Dow Corning) was added to powdered color (Blue Crayola powder paint and Red Crayola powder paint: Binney \& Smith, Easton, PA) and thinner (200 fluid 5.0 CS; Dow Corning, Midland, MI). Finally, the catalyst (Catalyst S; Dow Corning) was added. The colored silicone was then injected into the vascular structures. Vessel clamps were used. The specimens were stored in formaldehyde solution for 2 weeks.

\section{Dissection}

The burr holes were $5 \mathrm{~cm}$ lateral to midline. The bony flap was removed by burr hole opening and gigle saw cutting. Coronal sutura, lambdoid sutura and vertex localizations were marked. The dura covering the cerebrum was removed to expose the cortical veins entering the SSS under a Zeiss dissection microscope. The SSS was measured to be $1 \mathrm{~cm}$ before the coronal and the lambdoid sutures and the confluens sinuum. The SSS was dissected from right and left sides and all draining veins were calculated and measured under a Zeiss dissection microscope. The number of veins draining to the SSS before the coronal suture, between the coronal suture and vertex, between the vertex and the lambdoid suture, and between the lambdoid suture and the confluens sinuum were calculated (Figures 1, 2, 3). The diameters of the veins were measured at the junction where they drain to the SSS. Lacunar width and length were measured. All measurements were made with a $0.1 \mathrm{~mm}$ sensitive caliper.

\section{Parameters}

\section{The SSS Diameter}

a) At the coronal suture level

b) At the lambdoid suture level

c) Before draining to the confluens sinuum

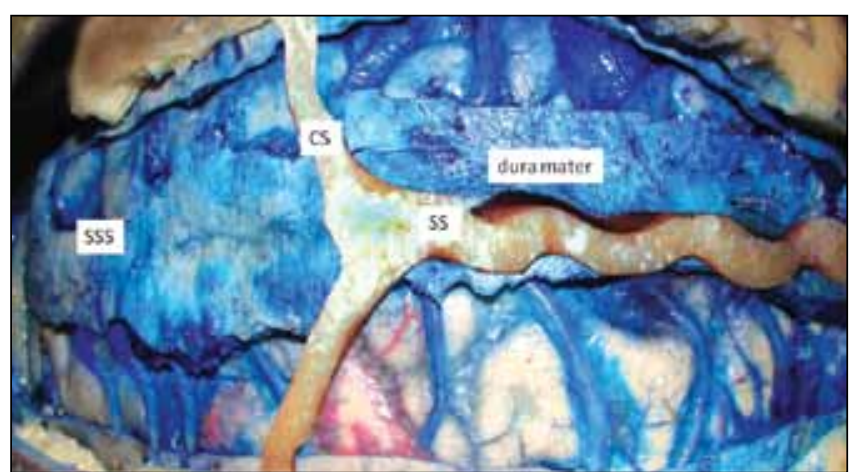

Figure 1: Sutures and superior sagittal sinus from superior aspect. SSS: superior sagittal sinus, SS: sagittal suture, CS: coronal suture.

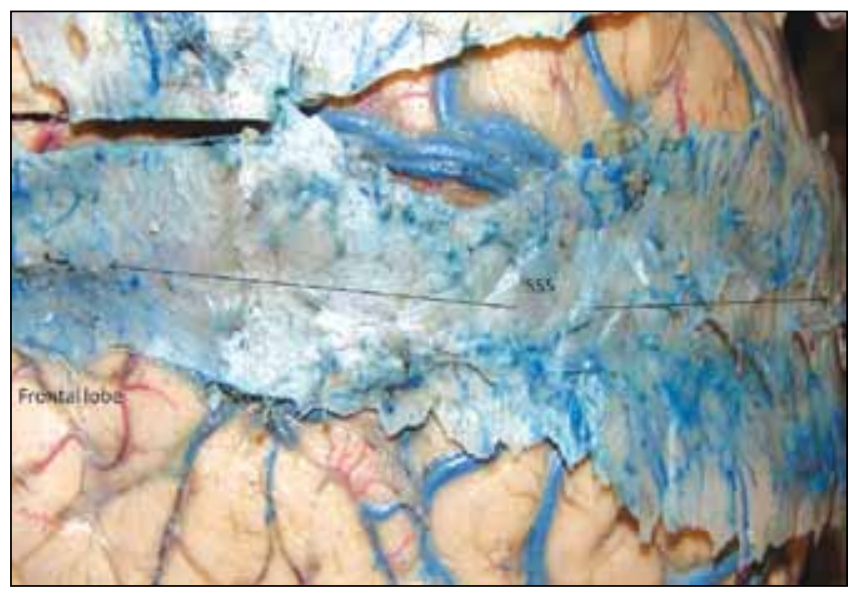

Figure 2: Superior sagittal sinus and superficial veins from anterosuperior aspect. SSS: superior sagittal sinus. 


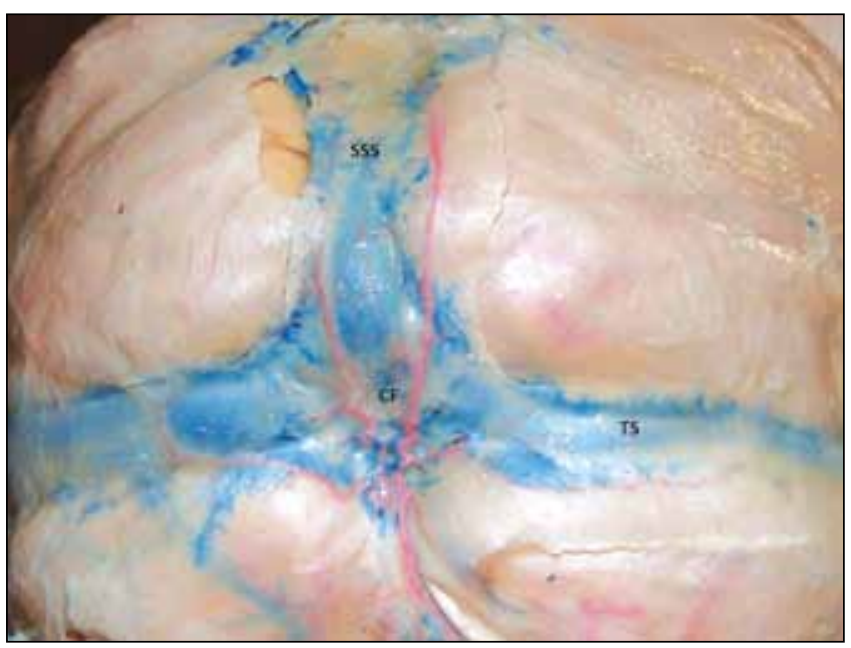

Figure 3: Superior sagittal sinus and confluens sinuum from posterior aspect. SSS: superior sagittal sinus, TS: Transvers sinus, CF: confluens sinuum.

\section{The number of veins draining to the SSS}
a) Anterior to the coronal suture
b) Between the coronal suture and vertex
c) Between the vertex and the lambdoid suture
d) Between the lambdoid suture and the confluens sinuum

\section{The diameter of veins draining to the SSS}
a) Anterior to the sagittal suture
b) Between the coronal suture and vertex
c) Between the vertex and the lambdoid suture
d) Between the lambdoid suture and the confluens sinuum

\section{The distance of veins to suture landmarks}
a) Veins anterior to the coronal suture
b) Between the coronal suture and vertex
c) Between the vertex and the lambdoid suture
d) Between the lambdoid suture and the confluens sinuum

\section{Lacunar morphometry}
a) Width of the lacuna anterior to the coronal suture
b) Width of the lacuna between the coronal suture and the lambdoid suture
c) Width of the lacuna between the lambdoid suture and the confluens sinuum
d) Lacunar length

SPSS for Windows 11.0 was used for the analysis. Minimum, maximum and average values were determined for the diameter of the SSS and the lacuna. Minimum, maximum and average vein diameters were determined both for right and left sides separately and for complete craniectomy. The right and left sides were compared using the student $t$ test. Lacunar morphometry was determined with regards to width and length.

\section{RESULTS}

In our study all specimens were found to have a midline sagittal suture and a single superior sagittal sinus (SSS) (Figure 1). None of the cadavers exhibited suture anomalies. In three out of six cadavers the SSS was $5 \mathrm{~mm}$ to the right of the sagittal suture, in two cadavers it was $3 \mathrm{~mm}$ to the left of the sagittal suture and in one cadaver the SSS was just under the sagittal suture. In the majority of specimens we examined, the SSS deviated to the right of midline.

\section{Diameters of the SSS}

The diameters of the SSS was $14.4 \pm 5.4 \mathrm{~mm}$ at the coronal suture, $13.1 \pm 1.6 \mathrm{~mm}$ at the lambdoid suture and $12.2 \pm 2.3 \mathrm{~mm}$ before draining to the confluens sinuum (Table I).

\section{The number of veins draining to the SSS}

We found a mean of $2.9 \pm 1.5$ veins draining to the SSS anterior to the coronal suture. There were a maximum of 7 and a minimum of 1 vein on the right side and a maximum of 4 and a minimum of one vein on the left side. We found a mean of $3.2 \pm 0.8$ veins draining to the SSS between the coronal suture and vertex. There were a maximum of 5 and a minimum of 3 veins on the right side and a maximum of 4 and a minimum of 2 veins on the left side. We found a mean of $2.3 \pm 0.9$ veins draining into the SSS between the vertex and the lambdoid suture. There were a maximum of 4 and a minimum of one vein on the right side and a maximum of 3 and a minimum of one vein on the left side. We found a mean of $0.3 \pm 0.5$ veins draining into the SSS between the lambdoid suture and the confluens sinuum. There was only one vein on both the right and left in only one cadaver at this point (Table II).

\section{The diameters of veins draining into the SSS}

The mean diameter of 36 veins draining into the SSS before the coronal suture was found to be $2.4 \pm 1.0 \mathrm{~mm}$. The mean diameter of 40 veins draining into the SSS between the coronal suture and vertex was found to be $3.0 \pm 1.2 \mathrm{~mm}$. The mean diameter of 27 veins draining into the SSS between the vertex and the confluens sinuum was found to be $2.4 \pm 0.7$ $\mathrm{mm}$. The mean diameter of veins draining into the SSS between the lambdoid suture and the confluens sinuum was found meanly $2.2 \pm 0.5 \mathrm{~mm}$. The diameter of one vein on the right side of one cadaver was $1.7 \mathrm{~mm}$ and the mean diameter of three veins on the left side of the same cadaver was $2.3 \pm 0.5$ $\mathrm{mm}$ (Table II).

\section{The distance of veins from landmarks}

The mean distance from the coronal suture of veins draining into the SSS before the coronal suture was found 11.3 \pm 9.1 $\mathrm{mm}$. On three cadavers, veins were just below the coronal suture. The mean distance from the coronal suture of veins draining into the SSS between the coronal suture and the 
vertex was found $19.4 \pm 14.6 \mathrm{~mm}$. One vein of one cadaver was just under the coronal suture. The mean distance from the lambdoid suture of veins between the vertex and the lambdoid suture was $16.8 \pm 7.9 \mathrm{~mm}$. There was only one vein in one cadaver after the lambdoid suture, $23.3 \mathrm{~mm}$ from the suture, and it was on the right side. The veins were a mean of $21.9 \pm 10.3 \mathrm{~mm}$ from the lambdoid suture on the left side. The mean distance from the lambdoid suture of veins between the lambdoid suture and the confluens sinuum was $21.9 \pm 10.3$ $\mathrm{mm}$ (Table IV).

Table I: The SSS Diameters

\begin{tabular}{|l|c|c|c|c|} 
& n & Minimum & Maximum & Mean \pm SD \\
\hline At the coronal suture level & 6 & $8.8 \mathrm{~mm}$ & $23.7 \mathrm{~mm}$ & $14.4 \pm 5.4 \mathrm{~mm}$ \\
\hline At the lambdoid suture level & 6 & $10.5 \mathrm{~mm}$ & $14.4 \mathrm{~mm}$ & $13.1 \pm 1.6 \mathrm{~mm}$ \\
\hline Before draining to the confluens sinuum & 6 & $9.4 \mathrm{~mm}$ & $15.2 \mathrm{~mm}$ & $12.2 \pm 2.3 \mathrm{~mm}$ \\
\hline
\end{tabular}

Table II: The Number of Veins Draining to the SSS

\begin{tabular}{|c|c|c|c|c|c|}
\hline Localization & & $\mathbf{n}$ & Minimum & Maximum & Mean \pm SD \\
\hline \multirow{3}{*}{ Anterior to the coronal suture } & Right & 6 & 1 & 7 & $3.3 \pm 2.1$ \\
\hline & Left & 6 & 1 & 4 & $2.5 \pm 0.6$ \\
\hline & Sum & 12 & 1 & 7 & $2.9 \pm 1.5$ \\
\hline \multirow{3}{*}{ Between the coronal suture and vertex } & Right & 6 & 3 & 5 & $3.5 \pm 0.8$ \\
\hline & Left & 6 & 2 & 4 & $2.8 \pm 0.8$ \\
\hline & Sum & 12 & 2 & 5 & $3.2 \pm 0.8$ \\
\hline \multirow{3}{*}{$\begin{array}{l}\text { Between the vertex and the lambdoid } \\
\text { suture }\end{array}$} & Right & 6 & 1 & 4 & $2.2 \pm 1.0$ \\
\hline & Left & 6 & 1 & 3 & $2.3 \pm 0.8$ \\
\hline & Sum & 12 & 1 & 4 & $2.3 \pm 0.9$ \\
\hline \multirow{3}{*}{$\begin{array}{l}\text { Between the lambdoid suture and the } \\
\text { confluens sinuum }\end{array}$} & Right & 6 & 0 & 1 & $0.2 \pm 0.4$ \\
\hline & Left & 6 & 0 & 1 & $0.5 \pm 0.6$ \\
\hline & Sum & 12 & 0 & 1 & $0.3 \pm 0.5$ \\
\hline
\end{tabular}

Table III: The Diameter of Veins Draining to the SSS

\begin{tabular}{|c|c|c|c|c|c|}
\hline Localization & & $\mathbf{n}$ & Minimum & Maximum & Mean士SD \\
\hline \multirow{3}{*}{ Anterior to the coronal suture } & Right & 20 & $1.1 \mathrm{~mm}$ & $4.4 \mathrm{~mm}$ & $2.5 \pm 1.0 \mathrm{~mm}$ \\
\hline & Left & 16 & $1.0 \mathrm{~mm}$ & $5.0 \mathrm{~mm}$ & $2.4 \pm 1.0 \mathrm{~mm}$ \\
\hline & Sum & 36 & $1.0 \mathrm{~mm}$ & $5.0 \mathrm{~mm}$ & $2.4 \pm 1.0 \mathrm{~mm}$ \\
\hline \multirow{3}{*}{ Between the coronal suture and vertex } & Right & 22 & $1.5 \mathrm{~mm}$ & $7.1 \mathrm{~mm}$ & $3.0 \pm 1.3 \mathrm{~mm}$ \\
\hline & Left & 18 & $1.3 \mathrm{~mm}$ & $5.5 \mathrm{~mm}$ & $3.0 \pm 1.1 \mathrm{~mm}$ \\
\hline & Sum & 40 & $1.3 \mathrm{~mm}$ & $7.1 \mathrm{~mm}$ & $3.0 \pm 1.2 \mathrm{~mm}$ \\
\hline \multirow{3}{*}{$\begin{array}{l}\text { Between the vertex and the lambdoid } \\
\text { suture }\end{array}$} & Right & 13 & $1.5 \mathrm{~mm}$ & $4.2 \mathrm{~mm}$ & $2.6 \pm 0.8 \mathrm{~mm}$ \\
\hline & Left & 14 & $1.5 \mathrm{~mm}$ & $3.5 \mathrm{~mm}$ & $2.3 \pm 0.6 \mathrm{~mm}$ \\
\hline & Sum & 27 & $1.5 \mathrm{~mm}$ & $4.2 \mathrm{~mm}$ & $2.4 \pm 0.7 \mathrm{~mm}$ \\
\hline \multirow{3}{*}{$\begin{array}{l}\text { Between the lambdoid suture and the } \\
\text { confluens sinuum }\end{array}$} & Right & 1 & - & $1.7 \mathrm{~mm}$ & $1.7 \mathrm{~mm}$ \\
\hline & Left & 3 & $1.8 \mathrm{~mm}$ & $2.7 \mathrm{~mm}$ & $2.3 \pm 0.5 \mathrm{~mm}$ \\
\hline & Sum & 4 & $1.7 \mathrm{~mm}$ & $2.7 \mathrm{~mm}$ & $2.2 \pm 0.5 \mathrm{~mm}$ \\
\hline
\end{tabular}


Table IV: The Distance of the Veins to Sutural Landmarks

\begin{tabular}{|l|l|r|r|r|c|}
\hline Localization & & $\mathbf{n}$ & Minimum & Maximum & Mean \pm SD \\
\hline \multirow{2}{*}{ Anterior to the coronal suture } & Right & 6 & $8.3 \mathrm{~mm}$ & $26.1 \mathrm{~mm}$ & $13.8 \pm 6.5 \mathrm{~mm}$ \\
& Left & 6 & $0 \mathrm{~mm}$ & $26.6 \mathrm{~mm}$ & $8.7 \pm 11.1 \mathrm{~mm}$ \\
& Sum & 12 & $0 \mathrm{~mm}$ & $26.6 \mathrm{~mm}$ & $11.3 \pm 9.1 \mathrm{~mm}$ \\
Between the coronal suture and vertex & Right & 6 & $3.3 \mathrm{~mm}$ & $27.4 \mathrm{~mm}$ & $12.9 \pm 10.4 \mathrm{~mm}$ \\
& Left & 6 & $0 \mathrm{~mm}$ & $47.4 \mathrm{~mm}$ & $26.0 \pm 16.0 \mathrm{~mm}$ \\
& Sum & 12 & $0 \mathrm{~mm}$ & $47.4 \mathrm{~mm}$ & $19.4 \pm 14.6 \mathrm{~mm}$ \\
Between the vertex and the lambdoid & Right & 6 & $11.2 \mathrm{~mm}$ & $26.3 \mathrm{~mm}$ & $16.5 \pm 5.5 \mathrm{~mm}$ \\
suture & Left & 6 & $4.4 \mathrm{~mm}$ & $34.3 \mathrm{~mm}$ & $17.0 \pm 10.2 \mathrm{~mm}$ \\
& Sum & 12 & $4.4 \mathrm{~mm}$ & $34.3 \mathrm{~mm}$ & $16.8 \pm 7.9 \mathrm{~mm}$ \\
\multirow{2}{*}{$\begin{array}{l}\text { Between the lambdoid suture and the } \\
\text { confluens sinuum }\end{array}$} & Right & 1 & & $23.3 \mathrm{~mm}$ & $23.3 \mathrm{~mm}$ \\
& Left & 3 & $7.6 \mathrm{~mm}$ & $32.2 \mathrm{~mm}$ & $21.4 \pm 10.3 \mathrm{~mm}$ \\
& Sum & 4 & $7.6 \mathrm{~mm}$ & $32.2 \mathrm{~mm}$ & $21.9 \pm 10.3 \mathrm{~mm}$ \\
\hline
\end{tabular}

Table V: Lacuner Morphometry

\begin{tabular}{|c|c|c|c|c|}
\hline Localization & $\mathbf{n}$ & Minimum & Maximum & Mean \pm SD \\
\hline Lakunar length & 6 & $73.4 \mathrm{~mm}$ & $107.8 \mathrm{~mm}$ & $97.7 \pm 12.8 \mathrm{~mm}$ \\
\hline Width of the lacuna anterior to the coronal suture & 6 & $13.3 \mathrm{~mm}$ & $20.0 \mathrm{~mm}$ & $16.3 \pm 2.5 \mathrm{~mm}$ \\
\hline $\begin{array}{l}\text { Width of the lacuna between the coronal suture and } \\
\text { the lambdoid suture }\end{array}$ & 6 & 0 & $31.3 \mathrm{~mm}$ & $20.9 \pm 11.3 \mathrm{~mm}$ \\
\hline $\begin{array}{l}\text { Width of the lacuna between the lambdoid suture } \\
\text { and the confluens sinuum }\end{array}$ & 6 & $13.3 \mathrm{~mm}$ & $21.1 \mathrm{~mm}$ & $17.4 \pm 2.6 \mathrm{~mm}$ \\
\hline
\end{tabular}

falx. The cortical veins may pass directly to the SSS, or they may join the meningeal sinuses, which empty into the SSS $(9,11)$. The cortical veins passing directly to the SSS may join the lateral angles, lateral walls, or inferior angle of the sinus. Other cortical veins join the meningeal sinuses in the dura mater over the convexity 0.5 to $3.0 \mathrm{~cm}$ lateral to the SSS. These meningeal sinuses course medially to join the lateral angle of the SSS. Several cortical veins may join a single meningeal sinus. Two or three meningeal sinuses may join to form a vestibule just before reaching the SSS. There is a tendency for the veins draining the lateral surface of the anterior frontal and posterior parietal regions to join the meningeal sinus in the dura mater lateral to the SSS. The veins from the posterior frontal and parietal region most commonly dip beneath the venous lacunae and pass directly to the SSS $(9,11)$.

Fox et al. demonstrated an extensive plexus of endothelialined channels stemming from the SSS along nearly its entire length but particularly along its anterior two-thirds. Intermittently, and particularly along the middle third of the SSS, these channels seem to coalesce into the lacunae. Their smallest branches embrace the arachnoid granulations that have herniated towards them from below. The endothelium lining these channels is morphologically the same as that lining the lacunae and the SSS, particularly the endothelium draping the granulations in these sites. This particular cell layer has been the subject of research efforts for many years and is thought to represent the final barrier for the absorption of cerebrospinal fluid (4).

Han et al. demonstrated that the way bridging veins enter the SSS varies in three dimensions, and thus the dural entrance of the bridging veins is difficult to locate precisely by digital subtraction angiography; the distribution pattern of the dural entrance of the bridging veins into the SSS is relatively constant and a segment of the SSS with no tributaries is centered at the coronal suture and is identifiable by digital subtraction angiography, and nearly all the bridging veins (97\%, 561/581) enter the SSS at an angle opposite to the direction of blood flow (6).

Numerous so-called "unpredictable" post-operative complications are likely to be related to the lack of prevention or non-recognition of venous problems, especially damage to dangerous venous structures. Tumors invading the major dural sinuses (the SSS, the confluens sinuum and the transvers sinus), especially meningiomas, leave the surgeon confronted with a dilemma: leave the fragment invading the sinus and have a higher risk of recurrence, or attempt total removal with or without venous reconstruction and expose the patient to a potentially greater operative danger (3). Conti et al. stated that treatment of parasagittal meningiomas by radiotherapy requires caution with adjacent venous structures. Conti et al. also described the importance of CT venography in parasagittal meningioma. In their study, which allowed the 
veins surrounding the meningioma to be easily identified and distinguished from the surface of the meningioma (2).

The number of veins draining to the SSS between the coronal suture and the lambdoid suture is considerably greater than the veins before the coronal suture or after the lambdoid suture (Table II). The anterior frontal region and posterior parietal-occipital regions are safer for surgical procedures. As Di Meco et al. mentioned, surgeons must protect veins between the coronal and lambdoid suture, especially in meningioma removal (3).

Surgery for parasagittal and falcine meningiomas requires meticulous preservation of the cortical veins that surround the tumour; thus, knowledge of the relevant venous anatomy would be extremely helpful during surgery. Khu et al. determined the number, size and disposition of cortical veins in relation to parasagittal and falcine menengiomas using virtual reality technology. This data showed that on average, there were 2.4 veins draining each anterior frontal region, 2.2 veins for the posterior frontal region, 1.6 veins for the parietal region and 1.1 veins for the occipital region (7). Our results were similar to Khu's (Table II).

In our study we measured the venous structures in relation to surgical landmarks. Many surgeons determine the pathology or surgical procedure by using surgical landmarks. In three out of six cadavers, the SSS was $5 \mathrm{~mm}$ to the right of the sagittal suture, in two cadavers it was $3 \mathrm{~mm}$ to the left of the sagittal suture and in one cadaver the SSS was just under the sagittal suture. Historically, the sagittal suture has been used as an external landmark to indicate the location of the midline portion of the SSS (16). In the majority of specimens we examined, the SSS deviated to the right of midline.

The importance of venous structures after anatomical dissections was mentioned by Rhoton (11), Oka (9), Schmidek (12), Tubbs (14,15), Vignes (18) and Yasargil (17). Tubbs (14,15), Rhoton (11) and Yasargil (17) in particular emphasized that the SSS gets larger and wider in posterior frontal and parietal regions and lacunar morphology also gets wider in the same region. In our study we also found the same results, which are summarized in Table I and V. The mean diameter of the SSS at the coronal suture level was $14.4 \pm 5.4 \mathrm{~mm}$ (minimum 8.8 $\mathrm{mm}$, maximum $23.7 \mathrm{~mm}$ ). The mean diameter of the SSS at the lambdoid suture level was $13.1 \pm 1.6 \mathrm{~mm}$ (minimum 10.5 $\mathrm{mm}$, maximum $14.4 \mathrm{~mm}$ ). The mean diameter of the SSS before draining to the confluens sinuum was $12.2 \pm 2.3 \mathrm{~mm}$ (minimum $9.4 \mathrm{~mm}$, maximum $15.2 \mathrm{~mm}$ ).

Vein diameter differs, especially in special areas of the brain. Movement, sensation, hearing and speaking areas have larger venous drainage than other areas. These areas have more venous anastomosis than other areas of the brain. Nature may want to protect these areas from occlusion or other dangers.

Oka et al. mentioned that veins draining to lateral surfaces are larger than veins draining to medial and inferior surfaces of the brain (9). We measured the diameter of veins from the foramen caecum to the confluens sinuum (Table III). Veins draining to the SSS between the coronal suture and the lambdoid suture were significantly larger than veins draining to the SSS before the coronal suture and after the lambdoid suture. Functional areas have larger venous drainage and neurosurgeons must pay more attention to protect these veins from occlusion or cutting. As previously mentioned by Yasargil, vein number and diameter decrease between the lambdoid suture and the confluens sinuum (17) .This may provide an advantage in surgical approaches to that region.

The coronal suture and the lambdoid suture are surgical landmarks for burr-hole or craniotomy procedures. We measured the distance of veins from these landmarks. As can be seen in Table IV, care must be taken at the coronal suture level. There may be veins just under the coronal suture. The furthest vein anterior to the coronal suture was $26.6 \mathrm{~mm}$ away from the coronal suture and the average was $11.3 \pm 9.1 \mathrm{~mm}$. Between the coronal suture and vertex, the furthest vein was $47.4 \mathrm{~mm}$ and the average distance was $19.4 \pm 14.6 \mathrm{~mm}$. For the lambdoid suture the nearest vein anterior to the suture was $4.4 \mathrm{~mm}$ away and the furthest vein was $34.3 \mathrm{~mm}$; the average distance was $19.4 \pm 14.6 \mathrm{~mm}$. Also veins can be seen on the lambdoid suture. The furthest vein posterior to the suture was $32.2 \mathrm{~mm}$ and the average distance posterior to the suture was measured to be $21.9 \pm 10.3 \mathrm{~mm}$.

As previously mentioned by Rhoton enlarged venous spaces, called lacunae, are contained in the dura mater adjoining the SSS (11). The lacunae are largest and most constant in the parietal and posterior frontal regions. Smaller lacunae are found in the occipital and anterior frontal regions. The lacunae predominantly receive the drainage of meningeal veins, which accompany the meningeal arteries in the duramater (11). In this study, we found that some cortical veins which empty into the SSS pass beneath lacunae rather than emptying directly into the lacunae. Some veins may share the same opening to the SSS as lacunae.

Lacunae were largest and most constant in the parietal and posterior frontal regions. Average lacuna length was $97.7 \pm 12.8 \mathrm{~mm}$. Average lacunar width anterior to the coronal suture was $16.3 \pm 2.5 \mathrm{~mm}$, between the coronal suture and the lambdoid suture it was $20.9 \pm 11.3 \mathrm{~mm}$, and between the lambdoid suture and the confluens sinuum it was $17.4 \pm 2.6$ $\mathrm{mm}$.

Cortical veins drain blood from a large part of the cerebral cortex to the SSS, which gradually becomes larger as it progresses from the rostral to the caudal region. The SSS is a rigid venous collector system, in contrast to the flexible cerebral bridging veins. Their walls lack abundant smoothmuscle fibers (18).

\section{CONCLUSION}

As the SSS enlarges in the posterior frontal and parietal regions, vein numbers and diameters also increase. We may see much venous anastomosis at the rolandic fissure. Also, lacunar morphometry becomes wider at the parietal region. By increasing the number of veins and their diameters, the 
brain protects the venous drainage of important regions from damage or occlusion. Many unwanted surgical venous complication may be prevented by paying attention to SSS and related structures. Also relationship of veins with surgical landmarks is valuable for neurosurgeons.

\section{REFERENCES}

1. Aboud E, Al-Mefty O, Yasargil G: New laboratory model for neurosurgical training that simulates live surgery. J. Neurosurg 97:1367-1372, 2002

2. Conti A, Pontoriero A, Salam I, Siragusa C, Midili F, La Torre D, Calisto A, Granata F, Roma P, De Renzis C, Tomas F: Protecting venous structures during radiosurgery for parasagittal meningiomas. Neurosurg Focus 27 (5): E11, 2009

3. Di Meco F, Li KW, Casali C, Ciceri E, Giombini S, Filippini G, Broggi $G$, Solero $\mathrm{CL}$ : Meningiomas invading the superior sagittal sinus: Surgical experience in 108 cases. Neurosurgery 55:1263-1274, 2004

4. Fox RJ, Walji A, Mielke B, Petruk KC, Aronyk KE: Anatomic details of intradural channels in the parasagittal dura: $A$ possible pathway for flow of cerebrospinal fluid (anatomical report). Neurosurgery 39(1): 84-91, 1996

5. Guvencer M, Sayhan S, Dereli NA, Tetik S, Yucesoy K, Arda $M N$ : Simulation of cerebrovascular circulation in the human cadaver for surgical neuroanatomy training. Turkish Neurosurgery 17(4):243-246, 2007

6. Han $\mathrm{H}$, Tao $\mathrm{W}$, Zhang $\mathrm{M}$ : The dural entrance of cerebral bridging veins into the superior sagittal sinus: An anatomical comparison between cadavers and digital subtraction angiography. Neuroradiology 49:169-175, 2007

7. Khu KJ, Ng I, Ng WH: The relationship between parasagittal and falcine meningiomas and the superficial cortical veins: $\mathrm{A}$ virtual reality study. Acta Neurochir 151:1459-1464, 2009
8. Kiya K, Satoh H, Mizoue T, Kinoshita Y: Postoperative cortical venous infarction in tumours firmly adherent to the cortex. J Clin Neurosci 8 (suppl 1):109-113, 2001

9. Oka K, Rhoton AL, Barry M, Rodriguez R:Microsurgical anatomy of the superficial veins of the cerebrum. Neurosurgery 17(5): 711-748, 1985

10. Park J, Hamm I-S: Anterior interhemispheric approach for distal anterior cerebral artery aneurysm surgery: Preoperative analysis of the venous anatomy can help to avoid venous infarction. Acta Neurochir (Wien) 146:973-977, 2004

11. Rhoton A Jr: The Cerebral veins. Neurosurgery 51(suppl 4): S159-205, 2002

12. Schmidek HH, Auer LM, Kapp JP: The cerebral venous system. Neurosurgery 17(4): 663-678, 1985

13. Sekhar LN, Chanda A, Morita A: The preservation and reconstruction of cerebral veins and sinuses. Journal of Clinical Neuroscience 9(4):391-399, 2002

14. Tubbs RS, Loukas M, Shoja MM, Apaydın N, Ardalan MR, Oakes WJ: Lateral lakes of Trolard: Anatomy, quantitation, and surgical landmarks. J Neurosurg 108:1005-1009, 2008

15. Tubbs RS, Loukas M, Louis RG, Shoja MM, Acakpo-Satchivi L, Blount JP, Salter EG, Oakes WJ, Wellons III JC: Anatomy of the falcine venous plexus. J Neurosurg 107:155-157, 2007

16. Tubbs RS, Salter G, Elton S, Grabb PA, Oakes WJ: Sagittal suture as an external landmark for the superior sagittal sinus. J.Neurosurgery 94:985-987, 2001

17. Yasargil G: Neurological Surgery, vol III. New York: Thieme Medical Publisher's Inc, 1987:327-330

18. Vignes JR, Dagain A, Guérin J, Liguoro D: A hypothesis of cerebral venous system regulation based on a study of the junction between the cortical bridging veins and the superior sagittal sinus. J Neurosurgery 107:1205-1210, 2007 